\title{
Sustainable Forest Management in Rural Southern Brazil: Exploring Participatory Forest Management Planning
}

\author{
André Eduardo Biscaia de Lacerda et al.* \\ Embrapa Forestry, Paraná \\ Brazil
}

\section{Introduction}

Historically, agriculture and livestock farming have been the main drivers of land cover conversion replacing natural forests in tropical and sub-tropical Brazil. The consequences for the landscape are well known: habitat fragmentation, biodiversity loss, and reductions in the quality of environmental services. The intense exploitation of natural forest resources tends to generate immediate, but limited, short-term economic wealth, which is generally very poorly distributed. In the long-term, forest resources are depleted thus reducing the ability of small rural owners to move out of impoverished situations. Therefore, while conversion of forest to agriculture can in some cases improve rural incomes, all too often deforestation leads to impoverishment of both ecosystems and communities. In Brazil, forest displacement in favour of agriculture and livestock has occurred since early in its colonization; in the Southern region - the principal agricultural area - this process took place in the late XIX and XX centuries. In this part of the country, past forestry practices such as clear-cutting and predatory harvesting, combined with social and legal encouragement, produced scenarios in which forested lands are now mostly degraded, not fulfilling their ecologic, social or economic roles in our society. In spite of the challenges that forest management faces in sub-tropical Brazil, some promising experiences and experiments are helping to create an environment receptive to the reintroduction of sustainable forest management (SFM) as a means to enhance economic incomes for rural property. Herein, we explore the obstacles related to the adoption of SFM as an economic alternative and propose technical opportunities for both small and large rural properties by presenting two case studies.

\footnotetext{
* Maria Augusta Doetzer Rosot'1, Afonso Figueiredo Filho², Marilice Cordeiro Garrastazú1, Evelyn Roberta Nimmo ${ }^{3}$, Betina Kellermann ${ }^{1}$, Maria Izabel Radomski ${ }^{1}$, Thorsten Beimgraben ${ }^{4}$, Patricia Povoa de Mattos ${ }^{1}$ and Yeda Maria Malheiros de Oliveira ${ }^{1}$

${ }^{1}$ Embrapa Forestry, Paraná, Brazil

${ }^{2}$ Midwest State University in Irati, Brazil

${ }^{3}$ University of Manitoba, Canada

${ }^{4}$ Rottenburg University of Applied Forest Sciences, Germany
} 
When the process of land conversion and the introduction of intensive land activities reached Southern Brazil, it found prosperous ground: timber harvested from the subtropical forests - especially the conifer Araucaria angustifolia - was Brazil's main export product during late XIX and early XX centuries. Sub-tropical forests were gradually reduced, plummeting to levels as low as $1-5 \%$ of primary forests. Today, the remaining forested areas are mostly secondary and in early or intermediary successional stages which are profit-limited in the short-term. However, the SFM potential of these forest areas should not be underestimated; they account for approximately $30 \%$ of the lands originally covered with forests in Southern Brazil. Environmental laws currently in place aim to protect forest cover through rigid control and bans on forest management, with a few exceptions at the small scale level, such as firewood collection for small farmers. Although environmental laws were mostly unsuccessful in avoiding deforestation, secondary forests have increased in the region.

The current set of state and federal legislation requires that at least $20 \%$ of the surface of most rural properties must be covered with forests and places severe restrictions on their use, while allowing for some agroforestry activities. Additionally, any waterway must have a forested buffer zone. Paradoxically, while aiming to prevent further deforestation, environmental legislation created an antagonism between forests and landowners to a point in which forest regeneration is avoided. In fact, rural properties that still have forested areas are drastically reduced in market value; the ultimate consequence is continued poverty in rural areas with an increasing economic disparity between urban and rural communities. This process contradicts the perception that forests should help in providing for basic needs of small landowners and forest communities, as well as the idea that the benefits and costs originating from maintaining forests should be shared by society as a whole and should not be a burden exclusively imposed on those remaining in rural areas. As a consequence, the restrictive legislation prevents forests from being used as a source of income while blocking any SFM initiative that, in the broad sense, includes recovery, conservation and long-term use. Although more recent experiences with payment for environmental services (PES) have helped to counter-balance the distortion in relation to sharing the costs of maintaining forests, such payments seem to be unfeasible even for family farms and forest communities. Although the challenge for meeting people's needs in rural areas and managing forests is not a problem restricted to Southern Brazil, it is particularly relevant as the region is characterized by a severely threatened forest type in an area where more than half a million small rural properties $(<50 \mathrm{ha})$ are subjected to near poverty conditions. The production of family farms accounts for about $10 \%$ of gross domestic product (GDP) and currently small farms account for $70 \%$ of food production. This figure demonstrates the economic importance of the sector.

In this paper we will explore some of the legal, social, economic and environmental issues related to the reduction of the forests in Southern Brazil and propose the implementation of a "locally adapted participatory sustainable forest management" (lapSFM) system focusing on reducing both rural poverty and deforestation. Finally, we discuss two case studies of participatory forest management in the south of Brazil. This paper aims to deliver scientific expertise translated into practical solutions related to land use and participatory SFM, considering a landscape approach for both small and large properties. The intent is to provide an evidence basis for changes in environmental policy to better reflect the enhancement of SFM in line with agroforestry and the use of tree genetic resources across the landscape, from forests to farms. 


\section{The Araucaria forest and the fragmentation process}

According to the "Ecosystems of the World Classification", edited by Lieth and Werger in 1989, the Subtropical Evergreen Seasonal Conifer Forest or Mixed Ombrophilous Forest is typically dominated by the species Araucaria angustifolia (Bertoloni) O. Kuntze (paraná-pine) (also known as Araucaria Forest). Although the species is predominant, the forest type also supports complex, variable and regional ecosystems commonly composed of more than one hundred woody species, some of which are endemic to this forest type. Araucaria forest occurs naturally in an area of 216,100 square kilometers, encompassing a region of mountains and plateaus throughout Southern Brazil (Figure 1). The region is characterized by altitudes above 500 meters elevation and a subtropical highland climate $(\mathrm{Cfb})$, where frosts might occur during the winter months or, less frequently, light snowfalls in the highest areas. Annual precipitation is high, ranging from 1,300 to 3,000 millimetres, without a dry season (Oliveira, 1999).

During the last century, Southern Brazil has experienced a rapid deterioration of its forest resources mainly due to land conversion, displacing forests for agriculture purposes as part of the colonization process and unsustainable selective logging of its commercial species. A central problem that is prevalent is determining how to manage the natural Araucaria forest fragments that remain. Some of these fragments are very small and are becoming poorer in terms of biodiversity because of intense human interference. The challenge is reconciling economic development and the conservation of biological resources and using the natural resources without destroying the possibilities for future generations. An important element in the efforts to save natural biodiversity is the establishment and maintenance of protected areas, as well as the sustainable management of the remaining areas.

Given the current situation, management strategies should be developed and applied to forest fragments in Southern Brazil in order to prevent the continuation of current processes of forest degradation and loss of biodiversity (Viana et al., 1992). Untended forests are more prone to disappear as they are gradually converted into other land uses that provide lower levels of ecosystem services and goods (Mc Evoy, 2004). In regions with intensive agriculture, protection against anthropogenic disturbance of these fragments is unlikely to be sufficient. A change from a top-down social relationship in which farmers are not sufficiently engaged in the process of developing environmental policies to a system that creates alternatives for natural resource use is likely one of the biggest challenges managers face in Brazil. There is an urgent need to reconcile local ecological knowledge (LEK) with environmental policies and natural resources protection with economic prosperity.

\section{Legal issues concerning forest management in southern Brazil}

Environmental law in Brazil is expressed mainly through the current Forest Code (Brasil, 1965) and subsequent regulations. The Forest Code considers that interventions in forested areas should be prescribed according to approved Management Plans (MP). However, for many years and in most cases, MPs have become synonymous with illegal logging practices. It was not until 1994 that the government defined SFM in practical terms through Decree 1.282 (Brasil, 1994). In establishing an official SFM policy, Brazil adopted the reduced-impact logging (RIL) concept as the basis for forest management (for the development of RIL see Putz \& Pinard, 1993; The International Tropical Timber Organization [ITTO], 1990; and Food and Agricultural Organization of the United Nations [FAO], 1993). The definition of a policy 
for forest management enabled Brazil to sign the Tarapoto Proposal of Criteria and Indicators (C\&I) in 1995, which forms the basis of sustainable management in Brazil's tropical forests. However, Brazil's legislation and signed international agreements focus on management of tropical forests; the need for regulating the use of forests in Southern Brazil (which are mostly subtropical) only began to be addressed more than a decade after the adoption of SFM in the Amazon.

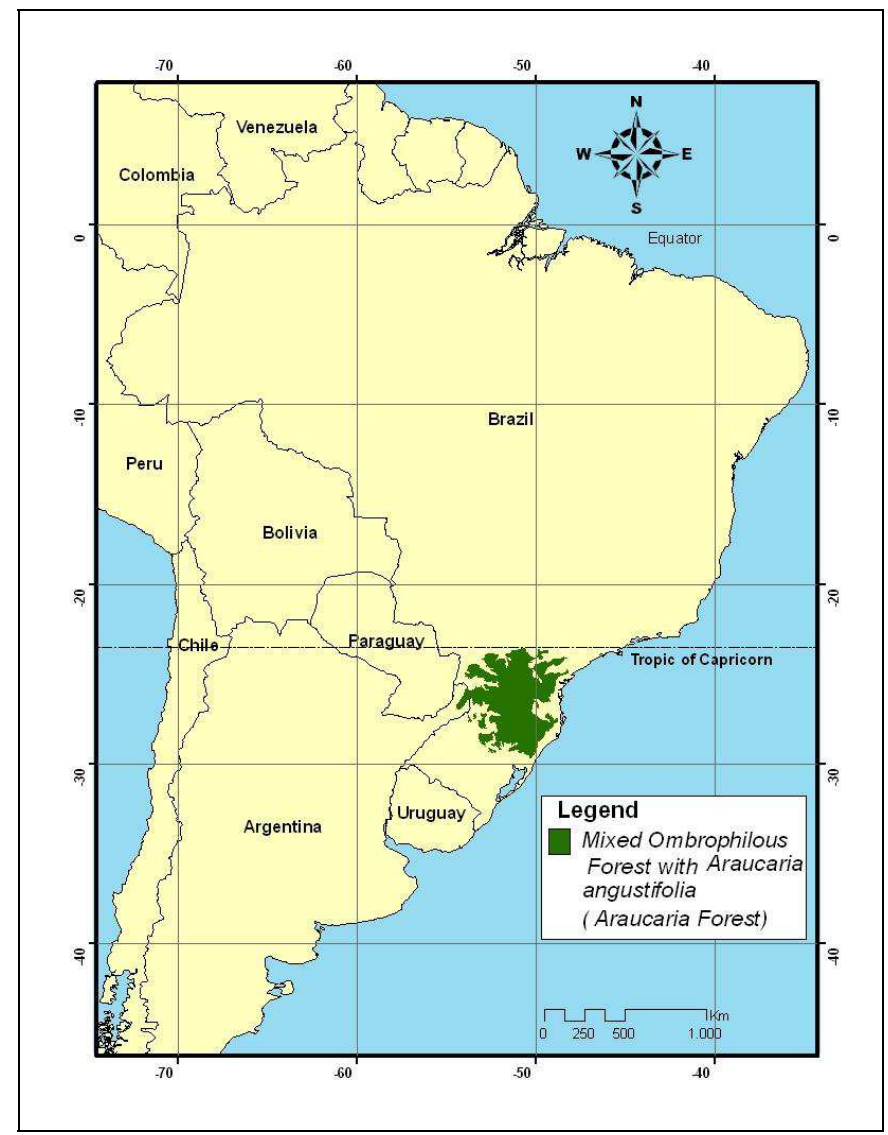

Fig. 1. Original geographic distribution of Mixed Ombrophilous Forest with Araucaria angustifolia

The first specific legislation concerning tropical and sub-tropical forests outside the Amazon biome was enacted in 2006 and is known as the Atlantic Forest Law (Brasil, 2006; 2008). This legislation, aiming to protect forest cover through rigid control, banned any land use that could potentially cause deforestation and restricted forest use to only non-commercial purposes based on the following regulations: a) management is permitted only when it does not produce tradable products or sub products, directly or indirectly; b) sustainable agroforestry management may be carried out in consortium with exotic species, in forestry or agricultural models (however commercial use of the wood from native tree species is 
forbidden); and c) forest management is forbidden unless the forest is composed of at least sixty percent of native pioneer tree species (and therefore restricted to very early successional stages). Furthermore, all forest management is subjected to environmental agency authorization. Additionally, Araucaria angustifolia and other important species are included in the list of "Endangered Species of the Brazilian flora" by the Ministry of Environment (MMA, 2008).

Given all the impediments to which Araucaria Forest is subjected, it is no wonder that many have given up on it. Landowners no longer consider the forest as a source of products and services; in many cases it is seen as an obstacle to other economic activities, especially agriculture. Although broad and specific legislation (especially the Atlantic Forest Law) on the management of Araucaria Forest resources have attempted to promote sustainable management through the diffusion of technologies, the management of forested areas is mostly forbidden. Therefore, it is a critical moment in a growing effort, championed by a group of researchers, to show that natural forests in Southern Brazil can be recovered and can be an important part of rural life.

\section{The development of a system for engaging local communities in natural resources management}

Before introducing the main components of our approach, it is important to clarify the terminology used. Initially, we understand that landscape level planning and management for natural resource governance (notably SFM) is the foundation of territorial zoning and follow the 12 principles, discussed and adopted by countries at the Convention of Biological Development (CBD). In applying the principles of the ecosystem approach, the following five points are proposed as operational guidance: a) focus on the relationships and processes within ecosystem; b) enhance benefit-sharing; c) use adaptive management practices; d) carry out management actions at the scale appropriate for the issue being addressed, with decentralization to lowest level, as appropriate; and e) ensure inter-sectoral cooperation.

Following FAO, SFM is defined as the stewardship and use of forests and forest lands in a way, and at a rate, that maintains their biodiversity, productivity, regeneration capacity, vitality and their potential to fulfill, now and in the future, relevant ecological, economic and social functions, at local, national, and global levels, and that does not cause damage to other ecosystems (FAO, 2005). This leads us to the idea behind "forest lands", which are defined by the US Forest Service as land at least 10\% stocked with live trees, or land formerly having such a tree cover, and not currently developed for non-forest use. The minimum area of forest land recognized is 0.40 ha (Smith et al., 2009).

The development of a land management system that could integrate multiple uses of natural resources with a participatory approach in a social and politically complex context was one of the first and most difficult challenges to overcome. By using traditional forest management concepts, adapted to the current stage of scientific knowledge and societal comprehensiveness, we introduced a participatory approach as a means to engage local communities in order to build a management plan that could provide landowners with ways to plan the use of their properties by combining agroforestry, forest management and natural resource conservation. The decision-making process uses local ecological knowledge (LEK) as part of the input necessary for establishing the goals and objectives and is based on the demands and interests of landowners. 
The conceptual foundation for the development of the method used in this paper is called Regeneration by Stands, a method focused on the management of forest resources. Forest management, for the purpose of this chapter, can be defined as the set of actions related to forested areas with a focus on its silviculture that aims to optimize the production of goods and services in a sustainable manner over time (Rosot, 2007); such optimization relies on identifying potential land uses which extends beyond currently forested areas. When planning the use of an area we must consider that multiple uses and functions cannot coexist simultaneously in the same place at the same time, consequently requiring the prioritization of tasks, the identification of preferred uses and the analysis of their compatibility and zoning (Gonzales et al., 2006). Furthermore, while designing an integrated plan we must consider all the resources and limitations that a property (or an area) may have. This process establishes a baseline considering multiple alternatives for managing land resources while decision-making takes advantage of the information available to determine specific actions for different areas considering a landscape approach (Rosot et al., 2006). By deciding the areas in which forests will play an economic and ecological role, a sustainable forest management plan can be defined as a means to organize the use of forest resources, which is intended primarily to ensure its perpetuity (Gonzales et al., 2006).

Here, we adapt Regeneration by Stands, one of the most successful forest management methods, as a means to integrate a participatory approach to the decision-making process with sustainable natural resources use. Regeneration by Stands has been widely implemented throughout Central Europe and has its historical origins in the work of Friedrich Judeich, in late nineteenth-century Germany. The method can be considered one of the most advanced planning systems currently available as it allows forest areas to respond effectively to the challenge of multifunctional management and conservation of forest resources (Gonzales et al., 2006). The system is based on maintaining a balance of age classes and the ability to generate goods and services from forests rather than turning it into a predetermined rigid pattern. This method differs from traditional methods of forest management mainly in relation to its short planning period, typically 10 years. As a consequence, management is based on continuous re-assessments in which the stands are evaluated in terms of their resources and respective use (i.e. objective and management applied); the system is therefore more flexible to changes such as forest fires, market demand, and land-owner interests, among others.

Hernando et al. (2010) applied the method of Regeneration by Stands for managing Natura 2000 forest sites in Spain, considering two different phases. In the first phase, the study area was divided in "stands", considered as any homogeneous patch of vegetation using Geographic Information System and Remote Sensing technologies and detailed fieldwork. The second phase evaluated the conservation status of each stand; the conservation status of the habitat was then obtained by integrating these values. Finally, forestry management measures were recommended for maintaining the favorable conservation status of the study area. These measures included consumption of the forest resources in such a way as to satisfy the objectives of both landowners and society (Brunson \& Huntsinger, 2008; Davis \& Johnson, 1987; Irvine et al., 2009). In Latin America the Regeneration by Stands method has not been implemented, with the exception of some studies in temperate forests in Chile (Rivera et al., 2002; Cruz et al., 2005).

Although some improvements in developing a sustainable forest system have been achieved, harmonizing different productive (economic) and conservation goals is still difficult to obtain. As stated above, in an ideal scenario a land management system should 
integrate multiple uses of natural resources which require knowledge from different areas of expertise. As a consequence, techniques applied to one activity should be balanced considering the outcomes in other areas. For example, conservation techniques used in agriculture should consider its effects on downstream water quality (e.g. no-till farming, green manure, among others) or the effects of agroforestry systems on increased crop pollination (and overall biodiversity). The multidisciplinary approach necessary for achieving integrated management might require specific solutions that can be designed using different expertise in a participatory system. However, in this paper we do not aim to detail agricultural alternatives, but rather consider some general principles that can be used to integrate agriculture with other land uses.

\subsection{Locally adapted participatory sustainable forest management system - lapSFM} The definition and implementation of the "locally adapted participatory sustainable forest management - lapSFM" system followed two main steps that are common to both scenarios, encompassing landscapes with both small and large rural properties. The system aims to deliver a Management Plan, as a part of a Roadmap (Figure 2), composed of different stages. The first phase - the Ecosystem Analysis - is related to the landscape as a whole, which can be a property, a set of properties, a municipality or a watershed, for example. The main purpose of this phase is to design territory zoning, based on spatially organized available information. For the purpose of this paper the second phase - the Management Plan - is related to the rural property and will focus not only on forested areas (forest) but also on forest lands, in which the forest component includes agroforestry, forest plantations and management of native fragments. Other designated zones, such as agriculture, are noted in the lapSFM but not discussed in this paper. The second phase also encompasses the monitoring activities of the implemented silvicultural treatments.

Phase 1: The initial step in the participatory forest management system refers to a broad analysis of the current environmental state of the area under consideration. It can be defined as a territory zoning which is based on the compilation of environmental data obtained from primary or secondary sources and requires initial land-use/land-cover (LULC) mapping. When possible, a landscape (or an ecosystem) approach is always the best way for dealing with large areas because of the managerial possibilities that planning at this level has for natural resource governance (notably SFM). Such a map should locate different land uses and different forest types and can be obtained either from satellite imagery (including Google Earth) or based on available ancillary information. In both cases a field verification of the classification is recommended as a means to update and check the gathered information. Additional cartographic, soil and hydrography layers can also be used and integrated into a GIS platform. The LULC mapping with the goal of creating territory zoning is a participatory process. Different stakeholders, including landowners, local government representatives, environmental agencies and academic institutions, for example, help in defining land use priorities and identifying the consequences of different decisions on the landscape configuration. LULC classes that are defined by environmental law as "restricted use" must also be mapped. For the forested areas or for forest lands, a procedure performed in a GIS platform can define the "forest stands", based on cross referencing the "territory zoning" layer and the "forest sub-typology" layer.

Phase 2: Following the territory zoning and the definition of the areas in which agroforestry (for forest land) and forest management (for forest) will take place either directly or indirectly, we define the techniques to be applied in forest management or other forest- 
based activities. This step involves the characterisation of forest stands (including areas to be planted or restored) and the definition of specific silvicultural treatments and/or other longterm actions to be put into practice for each stand. The characterization of forest stands is an initial step that aims at creating a rule of thumb for correlating the types of forests found in Southern Brazil and potential uses and management options. In this system, the vegetation present in an area is characterised by its structure, species composition, successional stage, threats and levels of degradation; this information is then correlated with the landowners' views in relation to the area and includes economic expectations and potential management practices. As a result, we can classify the current stage of conservation of most Araucaria Forest into five different vegetation types (discussed further below) which we denominate as Management Units - MUs.

lapSFM System Roadmap

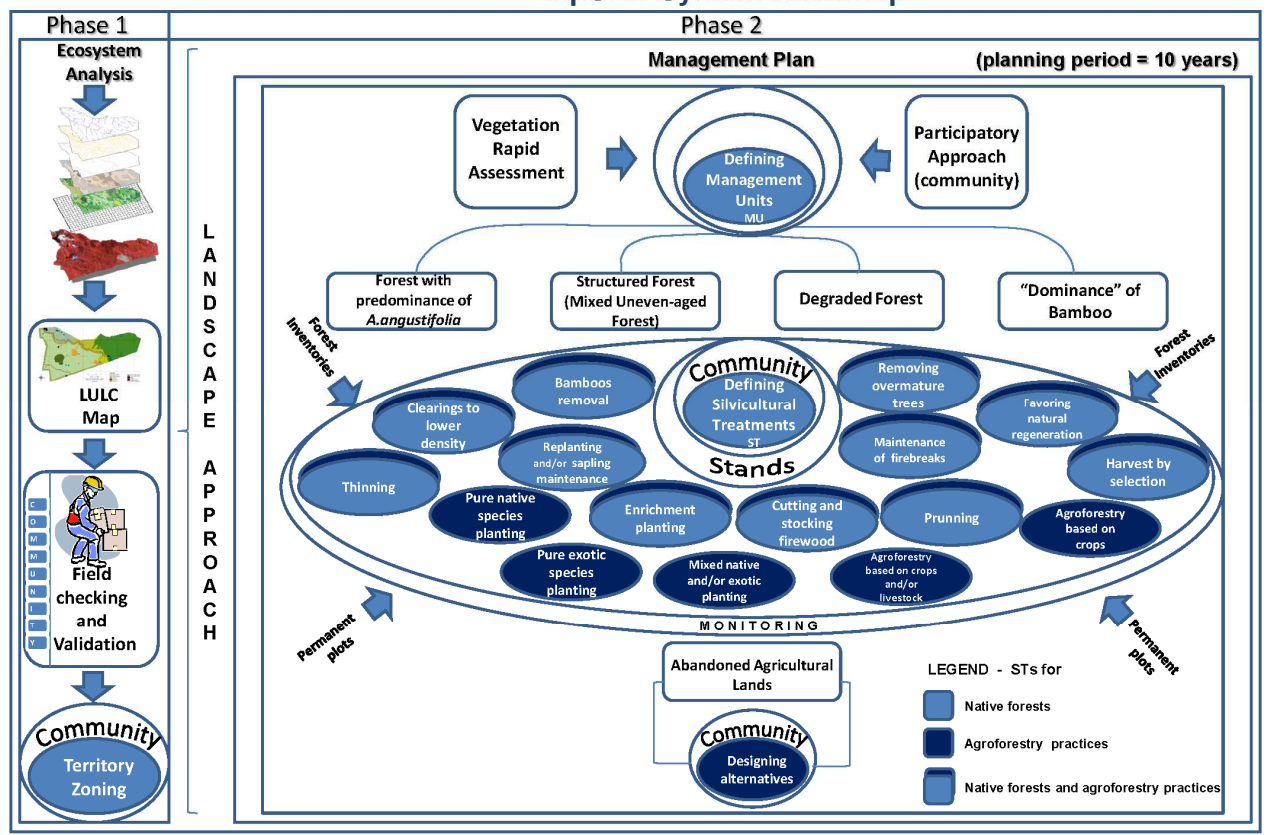

Fig. 2. lapSFM System Roadmap

The broad characterisation of each MU allows for the definition of a set of specific management actions aimed at achieving their pre-defined goals. Each MU is defined by the available information and by in-site checking which confirms the groups and general management actions; in each area (or stand) it is recommended that a rapid forest inventory take place to complement the information on the available resources which will support the actions to be applied. Based on the goals of each MU, general and specific silviculture approaches are proposed. Depending on the MU, different actions are expected to take place, such as thinning (and definition of which plants to be favoured), planting, pruning, removal/introduction of trees or species or no treatment at all. Specific decisions such as plants to be removed or planted are made in the field during designated field visits established in the lapSFM. 
As the classification of land cover into MUs is a participatory process which allows for the inclusion of historical, cultural and economic inputs, its application is not only restricted to a vegetation classification but instead aims at integrating social, environmental and economic variables.

The five MUs are:

Forest with Araucaria predominance MU1 - this MU is a general designation for all places whose canopy is dominated by Araucaria angustifolia (paraná-pine) regardless of the forest structure, composition, and current use. However, under this land use classification it is possible to identity different levels of canopy cover which are related to forest dynamic processes, especially for natural regeneration. In situations where the canopy has a higher density $(>70 \%)$ of predominantly overmature (remnant) paraná-pine trees, a near absent natural regeneration is observed. This process seems to be related to paraná-pine life cycle ( $\sim 400$ years) which creates light conditions on the forest floor below the limits required for seedlings to thrive; this situation is sometimes exacerbated by the presence of Dicksonia sellowiana and other species of fern. On the other hand, when a more open canopy is present, the ability for a regular natural regeneration to occur depends on whether bamboo species Merostachys skvortzovii and others are present or not as they take advantage of favorable light conditions and form a homogenous stratum that prevents any regeneration. Although both situations might require natural resources management through direct intervention, legal and political factors constrain most initiatives, leading to land abandonment. Such a situation tends to cause a gradual degradation of forest structure and floristic composition as a result of trees senescence and lack of regeneration accompanied with further bamboo spreading. Although current legislation was designed to halt deforestation it also resulted in farmers no longer holding decision-making power over land use. Their reaction was to convert forested areas into other uses (also by illegal means); this counter-productive situation if not tackled will result in more natural resources degradation while contributing to continued legal, economic and ownership insecurity.

Structured Forest (Mixed Uneven-aged Forest) MU2 - Structured Mixed Uneven-aged Forests correspond to secondary forests - regardless of whether or not they contain remnant trees - that have a diversified vertical structure, high tree species richness and in some cases, accumulation of forest biomass and volume. This forest is multi-strata structured with a canopy dominated by shade-tolerant and remnants of intolerant species with one or more additional tree strata. Natural regeneration is abundant with high species diversity, although the development of saplings is severely reduced when the understory is dominated by bamboo. For its structural complexity and the available forest biomass, classical methods of forestry (e.g. group or single-tree selection) may be applied to improve its composition and optimize biomass production with reduced impacts.

The MU2 is considered an ideal type for forest management as it has a developed horizontal and vertical structure. Although it is a secondary forest, its management could include the removal of trees for lumber and firewood as a result of the thinning of trees with undesirable characteristics (multiple stems, rotten, broken) as well as removing senescent pioneer trees (e.g. Ocotea puberula). The main goal of the management is to provide more light for regeneration and the development of commercial or ecologically important trees. In addition to thinning, controlling bamboo might be necessary as some species commonly find ideal conditions and tend to become invasive. In the early stages of bamboo development, mostly during seed germination following entire population die-offs, it is possible to control the re-population by a manual sapling removal. However, in most 
conditions repeated cutting using brushcutters with or without additional procedures such as chemical control might be necessary.

Degraded Forest MU3 - in the context of this project Degraded Forests are considered as forests that have suffered intensive logging and may have been affected by forest fires which caused a significant reduction in biomass and volume, as well as substantial changes to their structure and floristic composition (see Lund, 2009 for degradation definition). Remnant trees are of low commercial value (hollow, broken, burned) and possibly rejected during earlier harvestings; such trees are mostly old-growth usually in the senescence process and may occur in densities ranging from 5 to 15 trees per hectare. Under an open canopy there is a variety of possible situations: a) gaps are invaded by short grass under which scarce regeneration is observed (estimated between 500 to 1,500 plants/ha); b) pioneer trees, such as Mimosa scabrella, Vernonia discolor and others, dominate and might advance in succession or might be invaded by bamboo species; c) a mix of vines, pioneer shrubs and grasses dominate the gaps in which few trees are observed. The relatively open canopy of this type of forest is the main factor that allows bamboo to develop into nearexclusive populations. Such invasive behavior has been observed throughout Southern Brazil. In this kind of forest, natural regeneration is in most cases absent and therefore requires intense understory and bamboo management in order to allow for any commercial or ecological purpose. However, considerable initial income might be possible by removing fallen wood and any wood resulting from the thinning of undesirable trees.

Dominance of bamboo MU4 - this management unit is characterized by the dominance of bamboo species (especially Merostachys skvortzovii Send.) that show an invasive behavior (although it is a native species) forming highly populated, near-exclusive communities under a very open canopy. When trees are present, it might be related to previous logging or pioneers that took advantage of the last bamboo die-off event; arguably this type of vegetation might not be considered a forest. Large volumes of wood remnants from harvesting and wood debris might be found which can be used for firewood and sometimes even for sawmill processing. This sub-type requires intensive bamboo management. The specific procedures will depend on the degree of bamboo development, but in general it is expected that controlling bamboo populations will increase natural regeneration. Just as in MU3, the control of bamboo can be done manually and with a brushcutter or in more extreme cases, through chemical control or even by using bulldozer blades to remove the plant and/or root systems. After bamboo removal, the development of pioneer species, especially Mimosa scabrella is intense depending on seed availability in the seed bank or nearby dispersion. The management of pioneer species, including practices such as thinning, is possible as early as the third year; pioneer communities can be further managed for agroforest or forest systems.

Abandoned agriculture land MU5 - this type of land cover is characterized by abandoned agricultural areas and is observed especially in small farms. The vegetation is variable and covered by herbaceous (including crops and invasive species regeneration), shrubs and pioneer trees which characterizes early stages of ecological succession. Generally these areas are no longer suitable for annual crops due to depletion in soil fertility following successive crop rotations, although strict environmental legislation and rural out-migration might also be factors in abandonment. Thus, depending on the situation, the state of fallow might last until soil fertility is restored, allowing for new crops, or abandonment continues and forest succession advances (note that legislation severely restricts any land use if succession reaches a stage dominated by pioneer trees). As an alternative to traditional agriculture, 
agroforestry can be adopted following a wide variety of practices characterized by the establishment of pure or mixed plantations that might include traditional crops, medicinal plants, trees (both native and exotic) and livestock, or simply allowing forest succession with or without management. In essence, agroforestry systems are here considered as practices that combine the spatial and temporal management of tree species with horticulture and animal husbandry. The main goals of agroforestry is to allow for the diversification of production and income and to use the different ecological interactions that a multi-species system can provide which also tends to promote more environmentally sustainable practices.

Along with the management of natural resources using one of the Management Units, it is also essential to monitor the development of each system as specific ecological dynamics might lead to unexpected results. Any silvicultural prescription will necessarily affect the forest in many ways with varying levels of intensity. Therefore, monitoring is a means of assessing the forest response to management practices over time and space. Traditional monitoring systems include the adoption of permanent plots to monitor changes in vegetation structure and composition, soil fertility, water quality and other components that combined determine if the pre-defined goals will be achieved, both economically and environmentally. In forested areas, the implementation of forest inventories can be used as the basis for the monitoring and sometimes is restricted to one or few forest components (trees, regeneration, epiphytes, etc.). Ideally, forest inventories are conducted on a regular basis through permanent or temporary plots. Other methods such as rapid ecological evaluations are also useful tools for identifying general trends in the forest dynamics. Whichever the method chosen, monitoring is very desirable as it allows managers to determine if expected objectives will be achieved. It is worth pointing out that monitoring should not be a task restricted to academic interests but should be used as a tool for decision-making. As a consequence, local communities should be involved.

The steps and MUs described are part of a lapSFM that can be applied to landscapes characterised by both small and large properties. However, as land tenure is variable together with cultural and economic factors, adaptable approaches are necessary and should reflect the context of local communities. In the case of large properties, often with a single or reduced number of owners, the management based on the proposed method is also feasible. However, it is of extreme importance that nearby properties are also engaged in discussing potential involvement and natural resources management (e.g. allowing local communities to manage non-wood forest products - NWFP). Such an approach also has the advantage of reducing tensions often found between large and small landowners. On the other hand, regions characterized by small properties in which the management of natural resources lack the scale to reach intended markets, along with the difficulty to produce and implement management plans, local communities are encouraged to act in co-operative systems and manage their forests following a common lapSFM.

\subsection{Case study 1 - Landscape characterised by small rural properties}

The implementation of the lapSFM in a landscape characterised by a mosaic of small properties took place in the southwest of Paraná State, (Southern Brazil) in an area of approximately 1,200 ha within the Imbituvão River Basin, municipality of Fernandes Pinheiro (2532'29.64"S, 50³3'44.58"W; Figure 3, A). The project was developed through an international cooperation initiative between the Rottenburg University of Applied Forest Sciences (Germany) and the Midwest State University in Irati (Brazil). The project was 
designed to test several alternative techniques for forest recovery and sustainable management, with the goal of producing timber and non-wood forest products (NWFP). The 40 properties that participated in the project are all considered small properties, based on State classification; however, a significant variation in size was observed as the properties range from 2.4 to 50.8 ha (average of $15.5 \mathrm{ha}$ ).
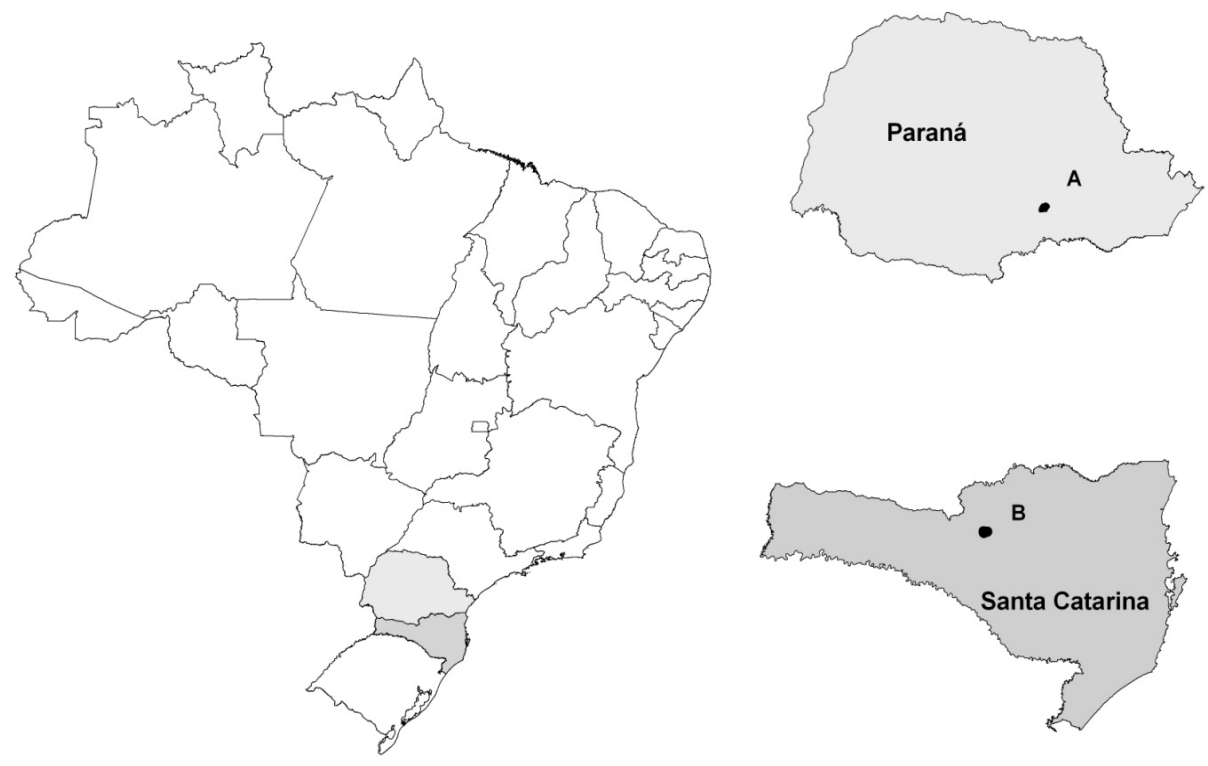

Fig. 3. Location of the study areas in Southern Brazil. A - Imbituvão River Basin. B Caçador Forest Reserve.

The region was chosen as it represents typical conditions in rural Southern Brazil in terms of its economy (agriculture based), social (low Human Development Index- HDI) and land tenure (properties $<50 \mathrm{ha}$ ) aspects. Additionally, the regional landscape is characteristic of Southern Brazil including a mosaic of forest and non-forest zones (Figure 4). Initially, properties were visited to introduce landowners to the project and, when possible, forest fragments and other land use areas were visited and described in order to conduct the Ecosystem Analysis (described above) and develop the land use and land cover (LULC) map. The process used tools such as a navigation GPS, questionnaires, cartographical maps and satellite images from Google Earth. An initial land use map was also prepared based on imagery and secondary data. The response from the local community was generally positive, with 40 small landowners engaged in the project. Interviews were carried out using structured questionnaires aimed at gathering data on property characteristics, current activities, social and economic factors, and views on natural resources issues (including expectations, difficulties, benefits, etc.).

In this project, permanent plots and on occasion forest inventories were implemented as part of the monitoring of the lapSFM and to gather information for the development of silvicultural treatments (STs). We engaged local communities in decision-making process by 
providing landowners with a tentative list of wood and non-wood species as a basis for defining species of interest and STs to be used. The STs were also presented as suggested options to be discussed and adapted if necessary. The information obtained from landowner's expectations and the Ecosystem Analysis was used to define a LULC map. As forest inventories and permanent plots were carried out by the supporting academic institutions, it is expected such information will be incorporated in the Management Plan revision as results become available.

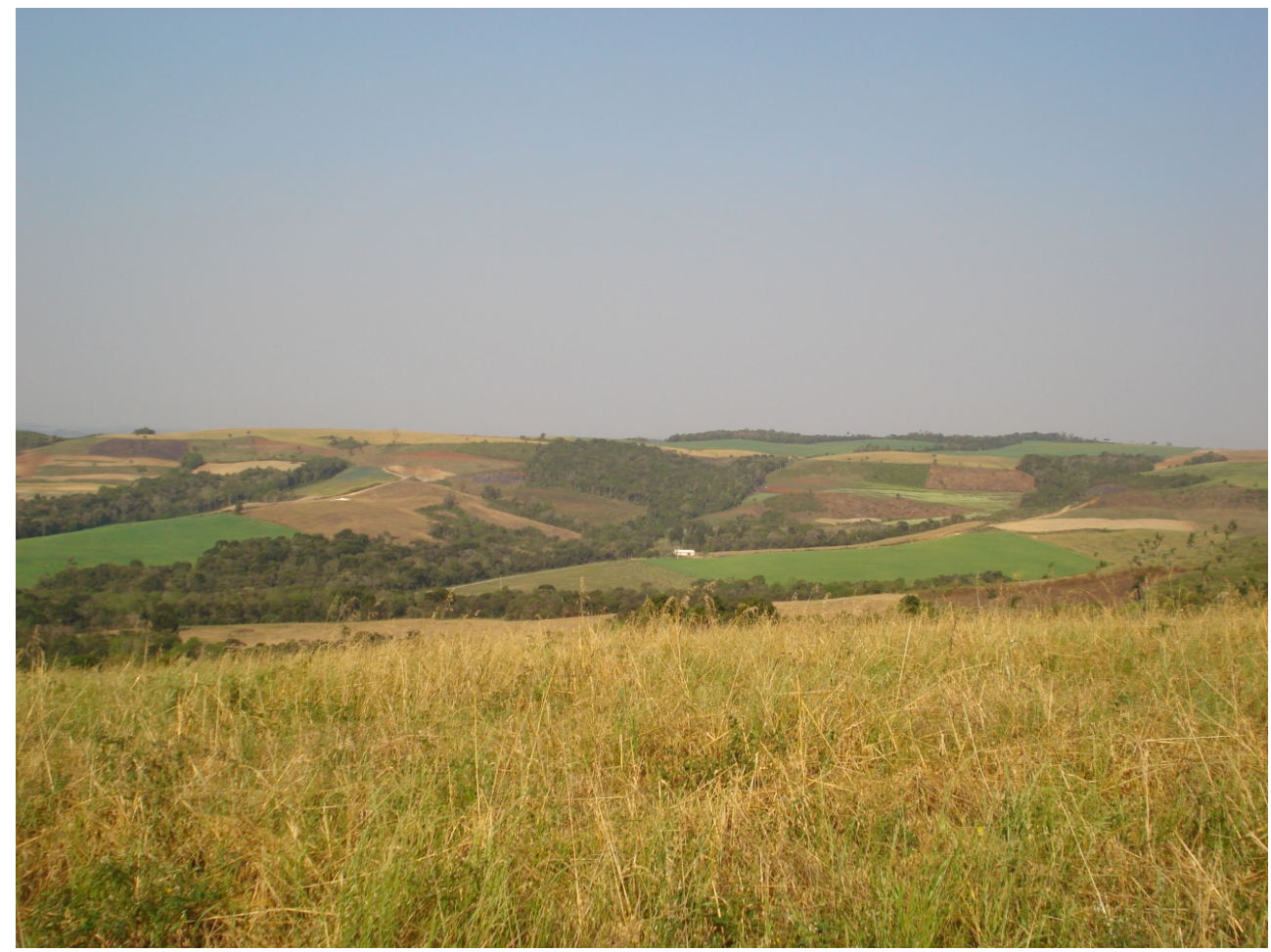

Fig. 4. Photo of the Imbituvão River Basin landscape which is characteristic of Southern Brazil.

The project also included a conservation component which was based on a landscape ecology approach aiming at conserving water resources and promoting biological conservation. A landscape analysis supported by the LULC map provided the basis for discussing with landowners the best areas and practices for enhancing connectivity between forested areas in order to create ecological corridors and to protect riparian ecosystems. The process of engaging landowners in those specific goals occurs through a process of negotiation and should not compromise families' income and decision-making power over the land.

The project proposed five silvicultural treatments (STs) following the logic presented in the lapSFM system Roadmap (Figure 2; see Table 1 for a summary of proposed STs and their correlation to original LULC). Each ST is briefly described as follows: 
- Exotic-native species system - this ST involves reforesting areas based on combining a eucalypt species (E. dunnii or E. benthamii) with approximately five native species. The main driver for this system was the need for landowners to comply with current legislation. As such, properties are required to have a minimum of $20 \%$ of their area covered with forests which also have very restrictive regulations regarding management; properties that do not comply are compelled to reforest in order to reach the required area. The need to put aside areas for forest protection usually causes dissatisfaction among landowners and reforestation systems that provide economical return are preferred. Due to the adaptation to regional climate and fast growth rates, eucalypt species have been planted in large scale commercial plantation programs in Southern Brazil and are also preferred by many landowners. Legislation permits use of exotic species if accompanied with native and different wood and non-wood species in the system.

- Pioneer species system - the system is based on the combination of bracatinga (Mimosa scabrella Benth.) - a fast-growth pioneer species - with other native species (minimum 5). This species has been traditionally managed through 30-year cycles after which the trees are logged and the land is burned to promote species regeneration. The species can be introduced by sowing, planting or simply managing the natural regeneration; other species included in the system are usually planted but managing natural regeneration is also possible. It is worth mentioning that $M$. scabrella is a leguminous species that allows nitrogen fixation in the soil and accelerates soil restoration.

- Mix of native species - this treatment combines different native species that are planted in mosaics based on their ecological requirements in order to hasten succession. This model is used mainly for restoration purposes as management might be restricted by current legislation.

- Enrichment planting - the system is based on planting native species in already forested areas in which commercial species can be planted. Usually the model is used in degraded forests and management is restricted by current legislation.

- Non-wood forest management - this is an agroforestry system that integrates management of forest species with non-wood products. There are different alternatives to be employed such as apiculture (native bees and Apis melifera), fruit production, Ilex paraguariensis (tea, mate and other products) and medicinal, aromatic and seasoning plants.

The challenges faced by the project include different social, economic and legal factors. As noted above, natural resources management is subject to restrictive legislation that constrains most technical alternatives. Therefore, landowners tend to avoid adopting any alternative that involves planting native trees due to the insecurity regarding future use. They may even feel compelled to reduce forested areas on their properties (which is in direct conflict with legislation). Additionally, the lack of a tradition of forest management tends to drive landowners to livestock or traditional agriculture which is perceived as unrestrained by the environmental legislation applied to forests. Finally, the small-scale production related to small properties usually does not find a market unless the owners are organised into co-operatives. Traditionally, rural communities are not well organized in Southern Brazil and several past experiences in the region show that in the long-term co-operatives rely on external assistance to maintain the organization. 


\begin{tabular}{|l|l|}
\hline Current land use and/or land cover & \multicolumn{1}{|c|}{ Silvicultural treatments (ST) } \\
\hline $\begin{array}{l}\text { Degraded (disturbed) forests, without } \\
\text { legal use restrictions }\end{array}$ & $\begin{array}{l}\text { Planting pure exotic/native or a combination; } \\
\text { thinning trees with unwanted characteristics } \\
\text { and planting NWFP; manage pioneer species } \\
\text { for timber and encourage succession } \\
\text { advancement. }\end{array}$ \\
\hline $\begin{array}{l}\text { Degraded (disturbed) forests with legal } \\
\text { use restrictions (riparian zones) }\end{array}$ & $\begin{array}{l}\text { Recovering using native species and an } \\
\text { indirect use of the area (Example: honey } \\
\text { production or decorative plant production; } \\
\text { removal and use of invasive tree species for } \\
\text { lumber, such as Hovenia dulcis (oriental raisin } \\
\text { tree)) }\end{array}$ \\
\hline Well structured forest fragments & $\begin{array}{l}\text { Thinning trees with unwanted characteristics } \\
\text { to improve timber stock; manage NWFP. }\end{array}$ \\
\hline $\begin{array}{l}\text { Non-forest or early stage of native } \\
\text { vegetation regeneration }\end{array}$ & $\begin{array}{l}\text { Enrichment planting (Example: } \text { Mate (tea), fruit } \\
\text { trees, Eucalyptus, Pine); mixed or pure stands }\end{array}$ \\
\hline $\begin{array}{l}\text { Non-forest (land use based on } \\
\text { agriculture and pasture) }\end{array}$ & $\begin{array}{l}\text { Agroforestry (Example: trees in contours, } \\
\text { shelterbelts, windbreaks or hedgerows; trees } \\
\text { along internal roads) }\end{array}$ \\
\hline
\end{tabular}

Table 1. Summary of the land use and land cover (LULC) and respective silvicultural treatments (STs) proposed for the Imbituvão River Basin case study

\subsection{Case study 2 - A large rural property in a small farmers mosaic}

In this case study, the "core" area chosen for implementing a lapSFM is the Caçador Forest Reserve, a 1,000-hectare Forest Reserve (not a conservation unit) which belongs to the Brazilian Corporation of Agricultural Research (Embrapa) and is located in the Araucaria Forest region (2532'29.64"S 50³3'44.58"W; Figure 3). Although the area was selectively exploited in the past, the Reserve has received no silvicultural interventions for the last 20 years as it was treated as a protected area (Kurasz, 2005). It is recognized as one of most well conserved forest remnants of Araucaria Forest and two of the most valuable timber species in the south can be found in the Reserve: Araucaria angustifolia (Araucariaceae), and Ocotea porosa (Lauraceae). Land tenure in the surrounding region consists almost exclusively of small farms and forest companies (Figure 5). Successive three-year research projects focusing on monitoring the Forest Reserve have been in-place since 2002 by Embrapa and other research and academic institutions. A significant amount of data has been collected over the years.

Following the Roadmap outlined above, the goal of this study is to develop a management plan, following Rosot et al. (2006). The first phase of the Roadmap, which includes land use planning/zoning in collaboration with local stakeholders has been completed. Currently we are in the midst of rolling out phase 2 by developing the forest management plan and associated monitoring activities. All MUs (described above) are represented in the Forest Reserve and therefore provides an excellent case study to examine the diverse forest types currently seen in Southern Brazil. The availability of data was a determining factor for the selection of the study area, as various studies have been conducted in the property and in its surrounding regions in the last ten years. A Geographic Information System (GIS) served as a basis for the territorial planning of the Reserve (Kurasz, 2005), which used mainly legal 
and environmental criteria - along with the expectations of the community - to define specific zones. These criteria led us to define Areas of Permanent Preservation (riparian vegetation), Areas of Restricted Use (like the Legal Forest Reserve) and unrestricted zones (Figure 6).

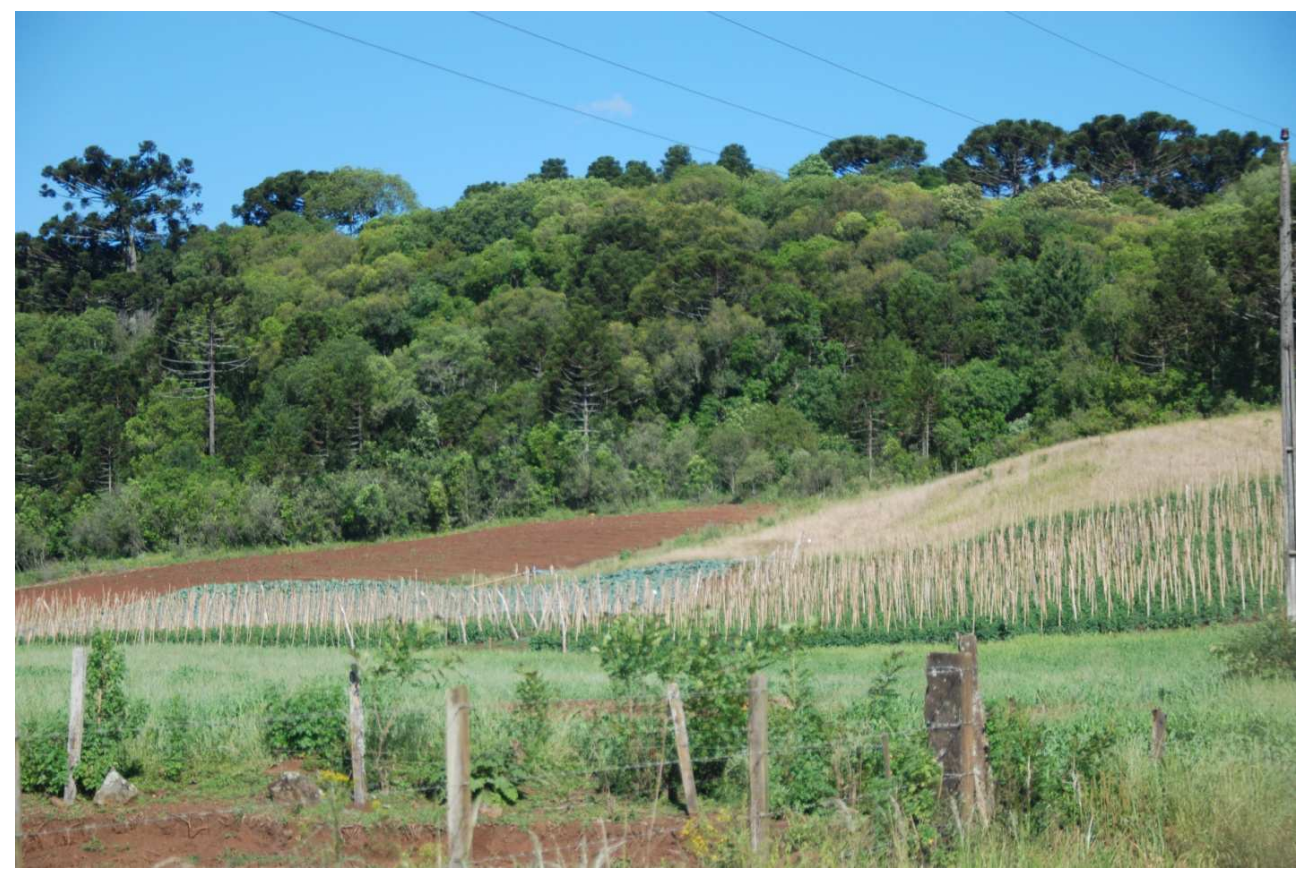

Fig. 5. Typical small farm property surrounding the Caçador Forest Reserve. Note the combination of different crops (tomatoes, cabbage) with hay for livestock and Degraded Forest MU3 with use limited to NWFP in the background.

The proposed zoning cannot be considered definitive, but it addresses legal and environmental constraints that must be considered when planning management activities and assigning uses to the area. Once the zones were mapped, landowners from the vicinity were invited to take part in the field checking and validation process.

The next phase involves the development of the forest management plan for the whole area, according to the previously defined zones. As a first step the area was divided into homogeneous management units (forest sub-typologies) by means of on-screen photo interpretation of Ikonos imagery and incorporating the information provided by the vegetation layer and the zoning layer available in GIS. The management units (MUs) represent groups of stands based on forest physiognomy for which the same type of silviculture could be applied (see above for detailed descriptions of MUs) (Figure 6). The initial and general objective is the recovery and improvement of the forest in terms of species composition and structure and to ensure the maintenance or rehabilitation of natural processes of plant succession.

The next step was to split the Forest Reserve into stands based on the intersection of MUs and the zones defined on the territory planning. Neighboring polygons belonging to 
different MUs or non-contiguous polygons belonging to the same MU constituted different stands. When a stand was crossed by rivers, roads or other physical obstacles, it was subdivided, thus generating two or more different stands (Figure 7).

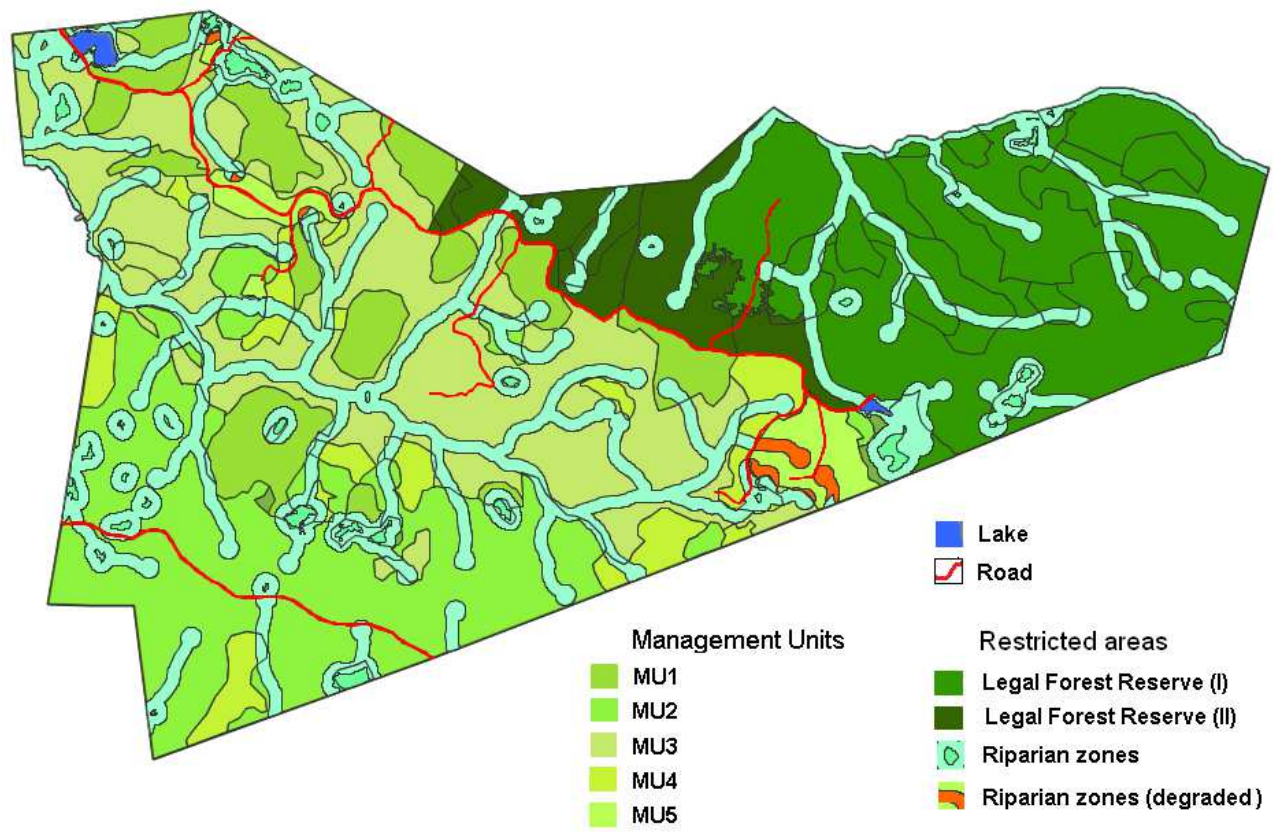

Fig. 6. Management Units and Zones, including Areas of Permanent Preservation (riparian zones), Areas of Restricted Use (like the Legal Forest Reserve), at Caçador Forest Reserve.

Silvicultural Treatments to be applied in each stand are composed of general silvicultural regimes for the respective type of vegetation, plus the special features that require the management of each stand based on its current situation. Site-specific silviculture is defined by the needs identified during the definition of management units and the objectives and constraints of management.

Although the Roadmap suggests that forest inventories should be carried out after MUs are defined, an inventory for Caçador Forest Reserve was already available due to previous research in the region. The existing survey aimed to assess the species composition and structure of the forest. During the survey a stratified random sampling was applied, considering 13 different strata which combined different slope and aspect classes. In addition, seventy-two temporary sample plots of $500 \mathrm{~m}^{2}$ (64 plots) and $250 \mathrm{~m}^{2}$ (8 plots) were distributed proportionally to the strata areas. In order to evaluate the composition, the horizontal and vertical structure of the forest, plant samples were collected for the species identification.

One of the preliminary outcomes of the integration of MUs with the inventory was to further define stands within the forest using a dynamic correlation in the GIS. One aspect of the analysis was a verification of the defined stands and an analysis of existing stock within each stand. As as a result, average timber stock and increment rates in terms of diameter, 
volume and basal area (Figure 8) are now available for each stand and together with other relevant information will further support management planning in the area.

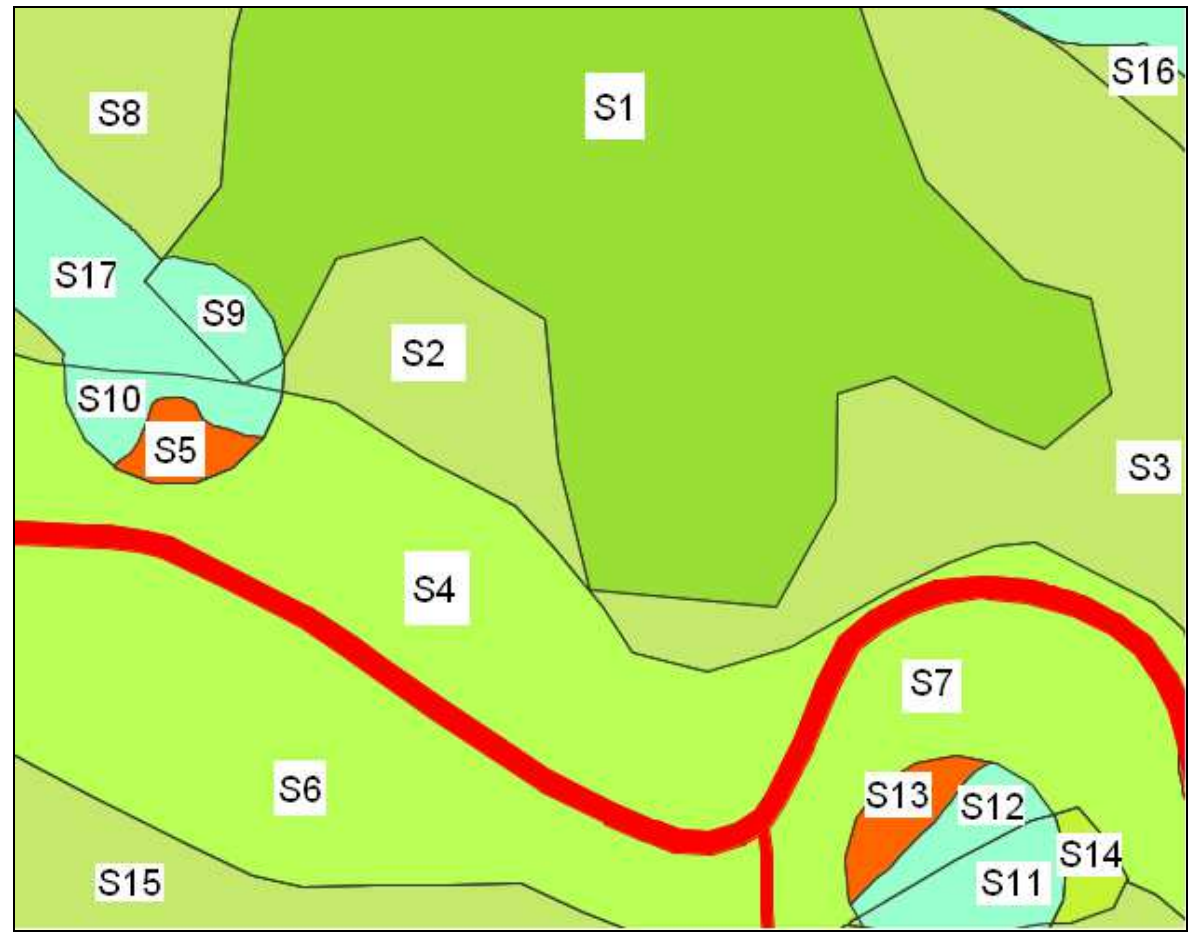

Fig. 7. Example of stand division at Caçador Forest Reserve.

Other preliminary results include:

- Local farmers showed interest in adopting forest management concepts in their properties, mainly through the implementation of agroforestry. However, there is still a general reluctance in engaging in forest management because of environmental law restrictions.

- There is widespread occurrence of native bamboo species that are impeding the development of forest species and causing the degradation of forest communities. This pattern was observed in all different MUs and in the most extreme cases, it was found that the phenomenon is restricting any forest regeneration. Intense human effort is necessary for controlling these species with promising initial results using a brushcutter. On the other hand, economic use can be considered for the removals.

- There is an important stock of firewood previously underestimated and not being considered as a source of income: more than $47 \mathrm{~m}^{3} /$ ha of firewood and $2.5 \mathrm{~m}^{3} /$ ha of lumber were found in the inventory.

- A comprehensive monitoring program is being carried out aiming to assess the response of forest stands to different silvicultural prescriptions through the observation and/or measurement of permanent plots. 


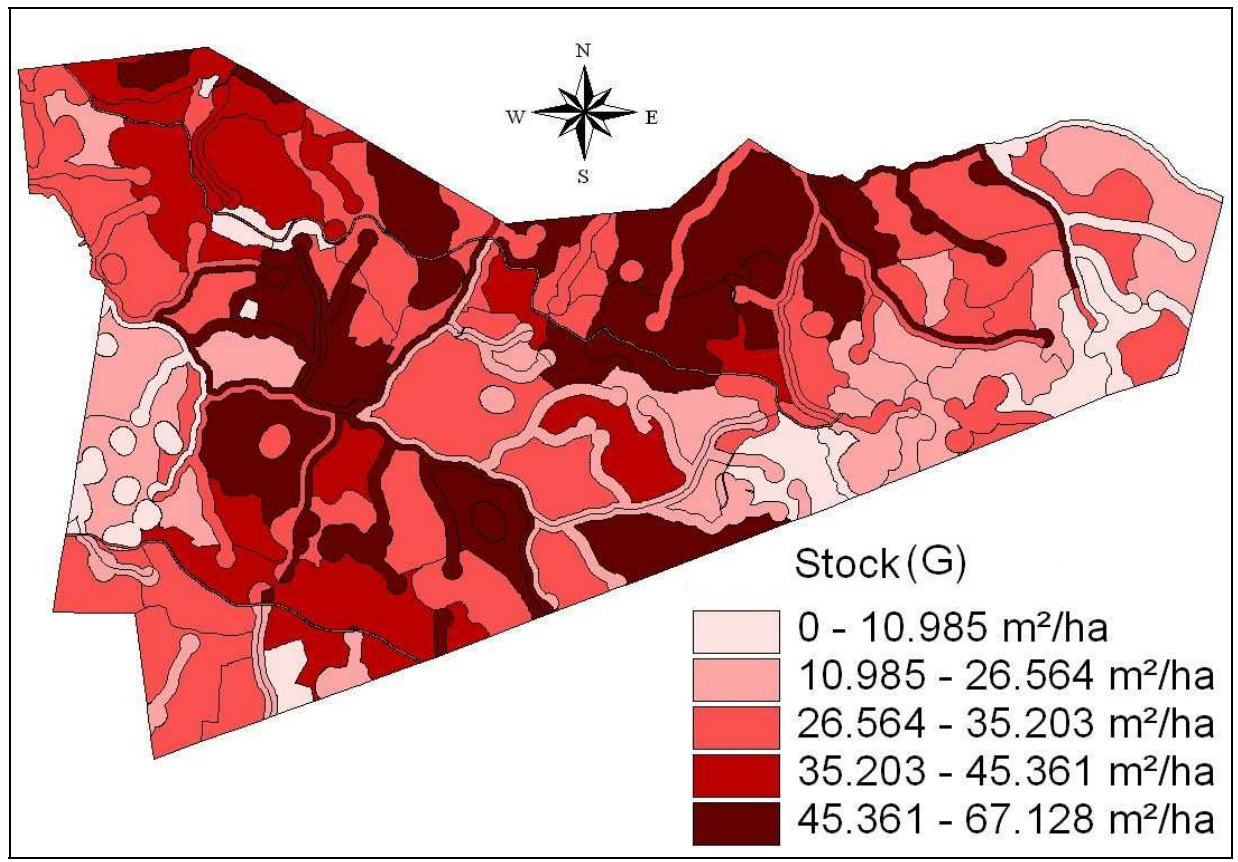

Fig. 8. Basal area $(\mathrm{G})$ classes for the Caçador Forest Reserve

\section{Conclusion}

In this paper we explored some of the legal, social and environmental issues related to the reduction of the forests in Southern Brazil and propose the implementation of a "locally adapted participatory sustainable forest management" system focusing on reducing both rural poverty and deforestation. Thus, two of the three main components of sustainability, the environmental and social aspects are being taking into account in the lapSFM roadmap. The economical aspect - the third component of sustainability - still needs to be fully developed in order to establish a complete framework for integrated natural resources management. However, in this chapter we discussed some of the problems that influence the economic environment that characterise rural properties (especially small ones) while introducing technical solutions for the management of natural resources. Finally, we aimed at shedding light on the discussion related to the current environmental legislation that we believe should be improved in order to achieve a more practical and homogenous accountability for the protection of the natural resources.

We discussed two case studies of participatory forest management in Southern Brazil through a Roadmap, built to customize practical solutions related to land use and participatory SFM, considering a landscape approach for both small and large properties. The intent was to provide a basis for changes in environmental policy to better reflect the enhancement of SFM in line with agroforestry, forest and non-wood forest resources use found throughout the landscape.

We addressed initially the lack of technical foundation for an integrated natural resources management (especially regarding forested areas) by introducing the lapSFM system. This 
system promotes a participatory approach through the engagement of landowners into the decision-making in order to combine land use interests with best practices. Furthermore, the system proposed integrates Local Ecological Knowledge - LEK - into the technical framework; as such, the result is a locally adapted management of natural resources. However, new approaches such as that outlined here face important challenges. Initially, it requires knowledge from different areas of expertise that is not always available, mainly in more isolated communities. Secondly, changing the top-down approach usually employed by technicians demands further training and willingness to share authority over decisionmaking. Thirdly, a turnover in mentality towards a group commitment for achieving common objectives might be a slow process; however, the introduction of co-operatives supported by adequate public financing and technical institutions is likely one of the best solutions for overcoming problems such as scale production. Finally, the most important contribution of this project is proposing solutions focused on enhancing economic prosperity tied to conservation.

By introducing production diversification, landowners can reduce their dependency on the price of globalized commodities that are mostly driven by policies at the national level focused on large-scale productions for international competition. In such situations, smallscale, unsubsidized agriculture (as subsidies and financing are generally designed for largescale business) has little chance of success. Managing the land in integrated systems of production that involve forests and agroforestry and allow for forest and non-forest wood products to be produced together with crops and livestock has the potential to lead to prosperity while protecting the natural resources.

The lapSFM system also re-introduces the forest component as an economic alternative for landowners. Current legislation that restricts land use together with antiquated ideas related to conservation and responsibility regarding natural resources has generated antagonism between farmers and forests. Although most forest fragments in Southern Brazil are found in small properties, the current legislation does not provide incentives for landowners to protect natural resources but rather only restricts land use and increases economic insecurity. As a consequence, while landowners are key elements in forest conservation, they solely carry the burden for maintaining land under protection. Altering this situation involves various strategies and includes changes in the legislation, public education and pro-active government policies. In the last few years, new public policies in Brazil have introduced programs for financing small-scale agriculture with clear beneficial consequences. Other policies such as the payment for environmental services (PES) have only recently started to be regulated and require further development and study. While PES has been used to promote reforestation and agroforestry, it is mostly used in the context of water protection. Many initiatives are now being implemented by states and municipalities and a National Policy of Environmental Services is being discussed in Congress. Ultimately such initiatives are helping to create a common ground on which relationships between landowners and forests can develop.

Other alternatives derived from international agreements such as REDD (Reducing Emissions from Deforestation and Forest Degradation) are important international policies and positive incentives relating to reducing emissions from deforestation and forest degradation in developing countries. In the second part of United Nations Framework Convention on Climate Change [UNFCCC] Conference in Copenhagen (2009), the importance of including the role of conservation, sustainable management of forests and enhancement of forest carbon stocks in developing countries was recognized in its initial 
rationale (called REDD+). Currently, REDD++ is being conceptualized and includes agroforestry, following Word Agroforestry Centre [ICRAF] reasoning (Akinnifesi, 2010).

The PES, REDD and ecosystem-based mitigation of greenhouse gases are all instruments of finance transfer between industrialized and developing countries in exchange for emission reductions associated with improvements in forest protection and management. However, commonly these international agreements get 'lost in translation' from the international and national level to forest landowners and communities. LapSFM is being built as a tool to help landowners in Southern Brazil, who are stewards of natural forest patches, be part of this new era, acknowledging that coherent public policies and legislation are necessary to link different levels of decision making - the international to the local.

\section{Acknowledgements}

This project was made possible through the cooperation of a number of agencies and institutions including: the Agricultural Research and Rural Extension Corporation of Santa Catarina (EPAGRI), Federal Technological University of Paraná (UTFPR), Rural Extension Institute of Paraná (EMATER/PR), and Environmental Institute of Paraná (IAP). We would like to thank the following institutions for their kind financial support: Brazilian Agricultural Research Corporation, Rottenburg University of Applied Forest Sciences, the Secretary of Science, Technology and Post-Secondary Education (SETI) of Paraná State, and the National Council for Scientific and Technological Development (CNPq). Finally, we would like to thank our colleagues for their assistance in developing and carrying out the research described herein, including: Ana Hernando, Arnaldo de Oliveira Soares, Carlos Henrique Nauiack, Carlos Roberto Úrio, Evaldo Muñoz-Braz, Fernando Luis Dlugosz, Flavia Colla, Gabriel Berenhauser Leite, Lisâneas Albergoni, Luziane Franciscon, Nelson Carlos Rosot, Osni Ruppel, Pablo Cruz, and Pilar Gallo.

\section{References}

Akinnifesi, F. (2010). Reducing emissions through agroforestry Research summary. Jotoafrika adapting to climate change in Africa. World Agroforestry Centre (ICRAF), No.4. pp. 5, ISSN 2075-556

Brasil. (1965). Lei n ${ }^{\circ} 4771$, de 16 de setembro de 1965. Institui o novo Código Florestal. Diário Oficial [da República Federativa do Brasil], Brasília. pp. 9529

Brasil. (1994). Regulamenta os arts. 15, 19, 20 e 21 da lei 4.771, de 15/09/1965, que institui o novo código florestal, e da outras providências. Diário Oficial [da República Federativa do Brasil], Brasília

Brasil. (2006). Decreto $\mathrm{n}^{\mathrm{o}}$ 11428, 22 de dezembro de 2006. Dispõe sobre a utilização e proteção da vegetação native do Bioma Mata Atlântica, e dá outras providências. Diário Oficial [da República Federativa do Brasil], Brasília, pp. 1

Brasil. (2008). Decreto $n^{0}$ 6514, de 22 de junho de 2008. Dispõe sobre as infrações e sanções administrativas ao meio ambiente, estabelece o processo administrativo federal para apuração destas infrações, e dá outras providências. Diário Oficial [da República Federativa do Brasil], Brasília. 23/07/2008, pp. 1

Brunson, M. W., \& Huntsinger, L. (2008). Ranching as a conservation strategy: can old ranchers save the new west? Rangeland Ecol Manag, Vol.61, No.2, (March 2008), pp. 137-147, ISSN 1550-7424 
Cruz, P., Honeyman, P., \& Caballero, C. (2005). Propuesta metodológica de ordenación forestal, aplicación a bosques de lenga en la XI Región. Bosque, Vol.26, No.2, (August 2005), pp. 57-70, ISSN 0717-9200

Davis, L. S., \& Johnson, K. N. (1987). Forest management. McGraw-Hill, ISBN 634-928-000000-000-0, New York

FAO. (1993). Forest resources assessment 1990: Tropical countries. FAO Forestry Paper, No. 112, ISBN 92-5-103390-0

FAO. (2005). State of the world's forests 2005, Food and Agriculture Organization of the United Nations, ISBN 97-892-510518-70, Rome, Italy

Gonzáles, J. M., Piqué, M., \& Vericat, P. (2006). Manual de ordenación por rodales. Gestión multifuncional de los espacios forestales. Norprint, ISBN 84-690-3133-3, Barcelona

Hernando, A., Tejera, R., Velázques, J., \& Ñuñez, M.V. (2010). Quantitatively defining the conservation status of Natura 2000 forest habitats and improving management options for enhancing biodiversity. Biodiversity and Conservation, Vol.19, No. 8, pp. 2221-2233, ISSN 0960-3115

Irvine, R.J., Fiorini, S., Yearley, S., McLeod, J. E., Turner, A., Armstrong, H., White, P. C. L., \& Van Der Wal, R. (2009). Can managers inform models? Integrating local knowledge into models of red deer habitat use. J. of Appl. Ecol., 46, 2, pp. 344-352, ISSN 0021-8901

ITTO. (1990). ITTO guidelines for the sustainable management of natural tropical forests. Technical Series 5. International Tropical Timber Organization, Yokohama, Japan.

Lund, H. Gyde. (2009). What is a degraded forest? White paper prepared for FAO. Retrieved from http://home.comcast.net/ gyde/2009forest_degrade.doc

Mc Evoy, T. J. (2004). Positive impact forestry: a sustainable approach to managing woodlands. Island Press. pp 268, ISBN 1-55963-788-9 Washington, D.C.

MMA. (2008). Instrução Normativa $n^{\circ}$ 6, de 23 de setembro de 2008. Reconhece espécies da flora brasileira ameaçadas de extinção e revoga a Portaria Normativa Ibama no 37N, de 3 de abril de 1992. Diário Oficial [da República Federativa do Brasil], Brasília de 24/09/2008, n 185, seção 1, pp. 75

Oliveira, Y. M. M. de. (2000). Investigation of remote sensing for assessing and monitoring the Araucaria Forest region of Brazil. Thesis (Doctor of Philosophy). Department of Plant Sciences, University of Oxford. Oxford.

Putz, F. E., \& Pinard, M. A. (1993). Reduced-impact logging as a carbon-offset method. Cons. Biol. 7, pp. 755-757, ISSN 0888-8892

Rivera, H. (2007). Ordenamento territorial de áreas florestais utilizando avaliação multicritério apoiada por geoprocessamento, fitossociologia e análise multivariada. Curitiba. Thesis (MSc). Department of Forest Engeneering. Universidade Federal do Paraná, Curitiba

Rivera, H., Rudloff, A. \& Cruz, P. (2002). Plan de Ordenación de la Reserva Nacional Valdivia. CONAF. Santiago

Rosot, M. A. D. (2007). Manejo florestal de uso múltiplo: uma alternativa contra a extinção da floresta com Araucária? Pesquisa Florestal Brasileira, Colombo, n. 55, pp. 75-85, ISSN 1809-3647

Rosot, M. A. D., Oliveira, Y. M. M. de, Rivera, H., Cruz, P. \& Mattos, P.P. (2006). Desarrollo de un modelo de plan de manejo para áreas protegidas en bosques con araucaria en el sur de Brasil, Proceedings of IUFRO Second LatinAmerican Congress. La Serena, Chile, October, 2006

Smith, W. B., Miles, P. D., Perry, C. H. \& Pugh, S. A. (2009). Forest resources of the United States, 2007. WO GTR-78. USDA Forest Service, Washington Office, Washington, D.C., USA. Retrieved from http://www.fs.fed.us/nrs/pubs/gtr/gtr_wo78.pdf 


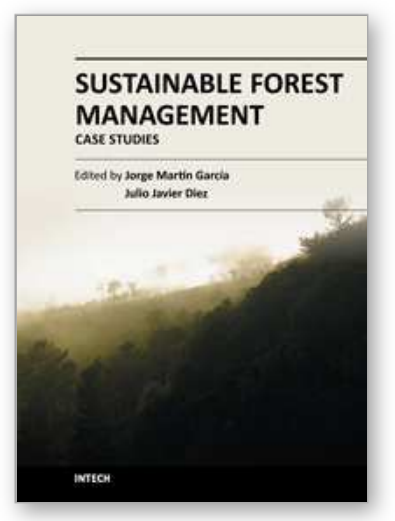

\author{
Sustainable Forest Management - Case Studies \\ Edited by Dr. Julio J. Diez
}

ISBN 978-953-51-0511-4

Hard cover, 258 pages

Publisher InTech

Published online 11, April, 2012

Published in print edition April, 2012

The concept of forest sustainability dates from centuries ago, although the understanding of sustainable forest management (SFM) as an instrument that harmonizes ecological and socio-economic concerns is relatively new. The change in perspective occurred at the beginning of the 1990s in response to an increased awareness of the deterioration of the environment, in particular of the alarming loss of forest resources. The book collects original case studies from 12 different countries in four continents (Africa, America, Asia and Europe). These studies represent a wide variation of experiences from developing and developed countries, and should clarify the current status of SFM worldwide and the problems associated with its implementation.

\title{
How to reference
}

In order to correctly reference this scholarly work, feel free to copy and paste the following:

André Eduardo Biscaia de Lacerda, Maria Augusta Doetzer Rosot, Afonso Figueiredo Filho, Marilice Cordeiro Garrastazú, Evelyn Roberta Nimmo, Betina Kellermann, Maria Izabel Radomski, Thorsten Beimgraben, Patricia Povoa de Mattos and Yeda Maria Malheiros de Oliveira (2012). Sustainable Forest Management in Rural Southern Brazil: Exploring Participatory Forest Management Planning, Sustainable Forest Management - Case Studies, Dr. Julio J. Diez (Ed.), ISBN: 978-953-51-0511-4, InTech, Available from:

http://www.intechopen.com/books/sustainable-forest-management-case-studies/sustainable-forestmanagement-in-rural-southern-brazil-exploring-participatory-forest-management-pla

\section{INTECH}

open science | open minds

\section{InTech Europe}

University Campus STeP Ri

Slavka Krautzeka 83/A

51000 Rijeka, Croatia

Phone: +385 (51) 770447

Fax: +385 (51) 686166

www.intechopen.com

\section{InTech China}

Unit 405, Office Block, Hotel Equatorial Shanghai

No.65, Yan An Road (West), Shanghai, 200040, China

中国上海市延安西路65号上海国际贵都大饭店办公楼 405 单元

Phone: +86-21-62489820

Fax: $+86-21-62489821$ 
(C) 2012 The Author(s). Licensee IntechOpen. This is an open access article distributed under the terms of the Creative Commons Attribution 3.0 License, which permits unrestricted use, distribution, and reproduction in any medium, provided the original work is properly cited. 